\title{
Ruído e idade: análise da influência na audição em indivíduos com 50 - 70 anos $* * * *$
}

\author{
Noise and age: influence on the hearing of individuals with ages \\ between 50 - 70 years
}

\begin{abstract}
Cláudia Giglio de Oliveira Gonçalves* Pedro Henrique de Miranda Mota** Jair Mendes Marques***
\end{abstract}

*Fonoaudióloga. Doutora em Saúde Coletiva pela Universidade Estadual de Campinas. Docente do Curso de Fonoaudiologia da Universidade Tuiuti do Paraná. Endereço para correspondência: Rua Felisberto Fiore Darozio, 146 - Curitiba - PR - CEP 82140-460 (clgiglio@terra.com.br)

**Médico Otorrinolaringologista. Doutor em Medicina pela Universidade Estadual de São Paulo. Docente do Curso de Fonoaudiologia da

Universidade Metodista de Piracicaba.

***Matemático. Doutor em Ciências Geodésicas pela Universidade Federal do Paraná. Professor da Universidade Tuiuti do Paraná.

*****Trabalho Realizado na Clínica Escola do Curso de Fonoaudiologia da Universidade Metodista de Piracicaba.

Artigo Original de Pesquisa

Artigo Submetido a Avaliação por Pares

Conflito de Interesse: não

Recebido em 28.02.2008.

Revisado em 26.08.2008; 01.09.2008;

27.11.2008.

Aceito para Publicação em 03.02.2009.

\begin{abstract}
Background: age and exposure to noise are among the factors that may cause hearing loss in adults. Both of these factors are considered additives once their combined effects can cause damage to the hair cells of the organ of Corti. Aim: to verify whether the exposure to occupational noise is an important risk factor for hearing disorders in adults with ages between 50 to 70 years, besides the auditory deterioration caused by age. Method: the audiograms of 71 men with ages ranging between 50 to 70 years were studied (cohort study), with the participants being divided in 2 groups (Group 1 with occupational exposure to noise and Group 2 without the exposure to noise) in order to compare their auditory profiles. Results: the groups do not present significant differences regarding age $(\mathrm{p}=0.321)$, with most of the participants with ages between 50 and 55 years (48); 14 subjects presented normal bilateral hearing thresholds and all of the others presented neurossensorial hearing loss. An association between noise and hearing disorders was found, with significant differences between the groups for auditory thresholds above $3000 \mathrm{~Hz}$, with Group 1 presenting worse results $(\mathrm{p}<0.05)$. Conclusion: the auditory thresholds of individuals with ages between 50 and 70 years are worse for the group that is exposed to noise. Noise is a higher risk factor than age when considering neurossensorial hearing losses.
\end{abstract}

Key Words: Deafness; Hearing Loss; Noise-Induced; Adult; Noise Effects.

\section{Resumo}

Tema: entre os fatores que podem causar alterações auditivas em adultos estão a idade e a exposição ao ruído. Estes fatores são considerados aditivos, pois seus efeitos causam danos nas células ciliadas do órgão de Corti. Objetivo: verificar se a exposição ao ruído ocupacional é um risco importante para as alterações auditivas em adultos na faixa etária de 50 a 70 anos, além do desgaste auditivo próprio do fator idade. Método: foram estudados (estudo coorte histórico) os audiogramas de 71 homens, de 50 a 70 anos, divididos em 2 grupos (Grupo 1 com histórico de exposição ocupacional ao ruído e Grupo 2 sem histórico de exposição ao ruído) para comparar-se os perfis auditivos. Resultados: os grupos não apresentam diferenças significativas em relação à idade $(\mathrm{p}=0,321)$ e há predomínio $(48)$ de sujeitos entre 50 e 55 anos de idade, 14 sujeitos com audição normal bilateral e os demais com perda auditiva neurossensorial. Encontrou-se associação entre ruído e alteração auditiva, com diferenças significativas entre os grupos para os limiares auditivos a partir de $3000 \mathrm{~Hz}$, sendo que no Grupo 1 estes foram piores ( $\mathrm{p}<0,05$ ). Conclusão: os limiares auditivos dos sujeitos com idade entre 50 e 70 anos estão piores no grupo exposto ao ruído. O ruído é um fator de risco maior do que a idade nas alterações auditivas neurossensoriais.

Palavras-Chave: Surdez; Perda Auditiva Provocada por Ruído; Adulto; Efeitos do Ruído. 


\section{Introduction}

Many are the factors that may cause alterations in hearing of adults, including aging, ototoxicity, cranial-encephalic traumatism, infect-contagious diseases, exposure to intense noise, hereditary succession, among others 1.

Hearing problems have an important impact in the life of people, and may induce social isolation due to the difficulties for participating in conversations, making frustrating any family meeting or social event 2 .

Among hearing alterations in adults, presbiacusy, or ear ageing, is quite common from 40 and 50 years of age and continues for the rest of life3. Age causes a gradual increase in hearing thresholds, and $4000 \mathrm{~Hz}$ frequency seems to be the most affected, principally in males 4 .

Presbiacusy can also be influenced by environmental and genetic factors, in other words, ear aging happens due to the hearing system natural "stress" and the cumulative effects of influences such as infections, traumas, exposure to noise or family predisposition 5 .

Noise, mainly in work environments, is an important factor which causes hearing alteration among adults, leading to noise-induced hearing loss (NIHL).

Studies in Canada pointed out that occupational noise is the most frequent cause of hearing alterations among adults, and an estimated eight to twelve adults in a thousand in the industrialized western region of that country 6 .

Studies have shown the effects of age and noise in hearing, considering the additive character of NIHL and presbiacusy, so the effects of them are superposed in the cochlea, harming hair cells 7-10.

The main factors of hearing losses among workers are exposure to occupational noise and age. Each one of these factors should be better evaluated as regards its contribution to hearing loss, allowing a better definition of the influence of noise in hearing and what is to be expected regarding age and sex.

The similarity between audiometric curves in NIHL and presbiacusy can make difficult evaluating the contribution each one of these factors has in the population group above 50 years of age, involving labor and legal implications, which are of interest for professionals of the area.

Thus, the objective of this study is to check whether exposure to occupational noise is an important risk factor for hearing damage in adults from 50 to 70 years of age, contributing to the reflection on the influence of age in the audition workers having NIHL.

\section{Method}

The studied population is assisted by a Audiology Clinic-School regarding hearing evaluation and it was submitted to anamneses, otoscopy and audiolometric evaluation, after having signed the term of informed consent to participate in the inquiry. The inquiry was approved by Research Ethics Committee under number 35/04 of Free and Informed Consent in the presence of the researchers.

Selection criteria of subjects were: being male, have from 50 years to 70 of age, not to present otoscopic alterations in the evaluation by a otorhinolaryngologist, not to present identified associated diseases (diabetes mellitus, systemic high blood pressure, rheumatologic diseases, labyrinthitis, conductive hearing loss, Ménière's disease, hypercholesterolemia and measles) and other conditions able to contribute to hearing loss and to influence results of the study, and not to present a history of exposure to non-occupational noise (noisy leisure).

The age group of the study (from 50 to 70 years) was defined considering the following factors: presbiacusy begins around 50 years of age 3; retirement due to age occurs at 65 years of age; there is in Brazil a higher concentration of old people in the age group of more than 70 years of age 11 and life expectancy for men in Brazil is 67.6 years 12 . Thus, it would be possible to analyze a population that already suffer hearing stress, but does not yet present occupational losses aggravated by age.

Subjects were divided in two groups: Group 1 (36 subjects) with a history of occupational exposure to noise (exposure to noise as a potential risk factor during the past professional life of the group) and I Group 2 (35 subjects) without historical of exposure to occupational noise.

The hearing thresholds of each ear were analyzed according to the groups. Such data were correlated with age and exposure to noise.

For analyzing results, descriptive statistics data were organized having as variables age and the time of exposure to occupational noise (only for Group 1). To evaluate the association of noise with hearing alterations, the relative risk was calculated. Complementing qualitative analysis, a quantitative analysis was carried out using Student's T test to check confidence for inferences. We used a confidence interval (CI) of $95 \%$ to describe the precision of the estimates. 
GRAPH 1. Description of measures obtained in frequency groups for subjects having the right ear exposed or non-exposed to noise.
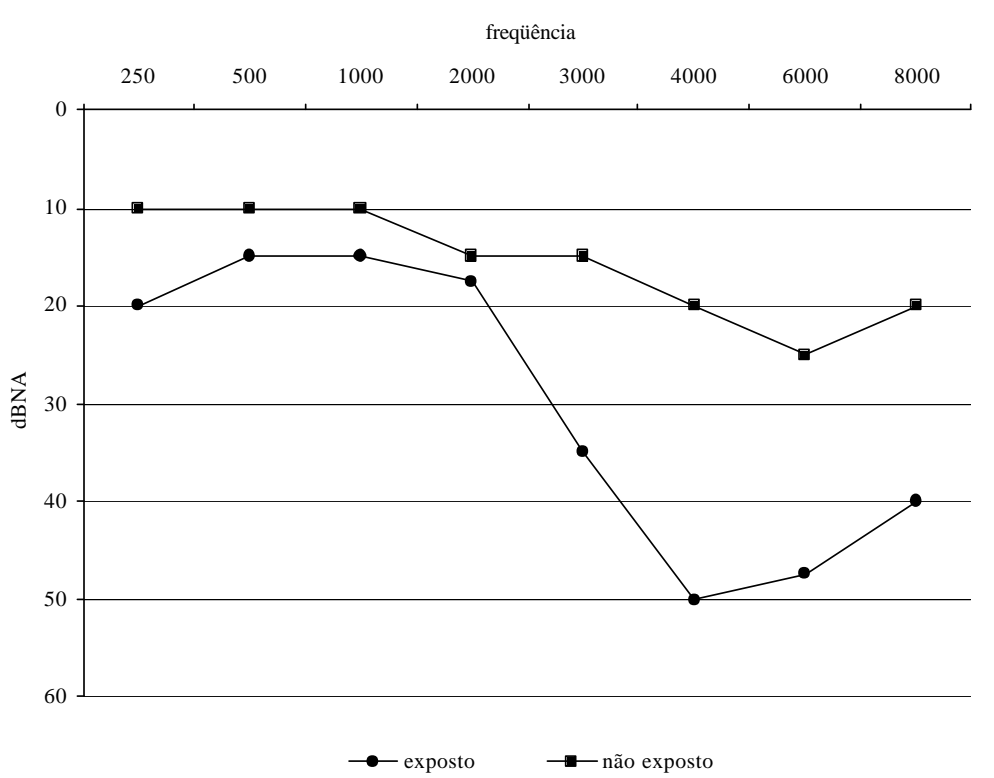

GRAPH 2. Description of measures obtained in frequency groups for subjects having the left ear exposed or non-exposed to noise.

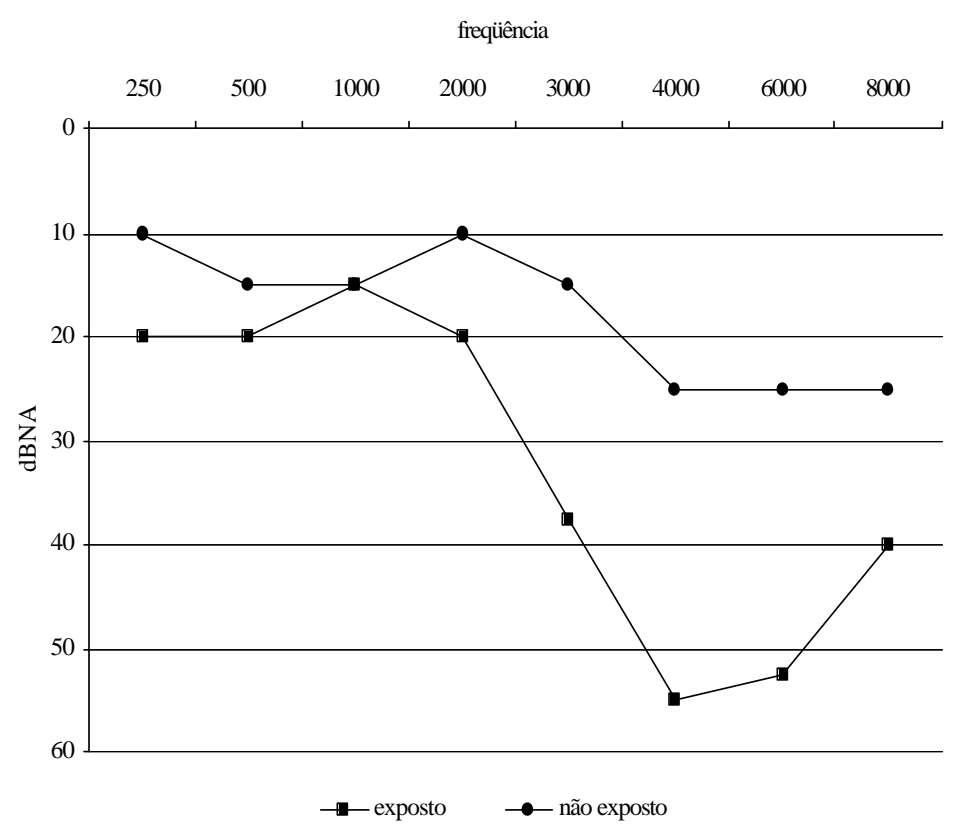

\section{Results}

We analyzed a total of 71 male subjects (36 of which having a history of occupational exposure to noise and 35 without occupational exposure). Most subjects $(67.6 \%)$ belong to the age group from 50 to 55 years.

The average of the age in the group as a whole (71 subjects) is 54 years of age (Standard deviation $\mathrm{SD}$ of 4.22). In the group exposed to noise the age average is $53.5(\mathrm{SD}=3.68)$ and in the group without historical of exposure to noise it is 54 years ( $\mathrm{SD}=$ 4.72). Considering a $5 \%$ significance level, there is no significant difference between the average ages of the two groups, with $\mathrm{p}=0.321(\mathrm{p}>0.05)$.

In the group with a history of exposure to occupational noise, average time of exposure is 19 years ( standard deviation $=4.51$ ), varying from eight to twenty two years. We analyzed the hearing profile of the studied group.

In the group without history of exposure to noise there is a higher number of subjects with normal audition (13) than among subjects with a history of exposure to noise (1). There is in the two groups, a a predominance of bilateral neurosensorial hearing loss (18 subjects without a history of occupational exposure to noise and 33 subjects with a history of occupational exposure to noise).

There is a significant degree of dependence between exposure to noise and neurosensorial hearing loss ( $\mathrm{p}<0.05$, significance level $=5 \%)$.

The subjects of this study, with ages from 50 to 70 years, when exposed to noise have more risk of developing hearing losses than those not exposed.

As for hearing tonal thresholds, we analyzed tonal averages for each frequency (Graph 1 and 2).

The averages tonal thresholds for 3000, 4000, 6000 and $8000 \mathrm{~Hz}$ frequencies were higher than the averages of tonal thresholds in the group with a history of occupational exposure to noise.

We found significant differences in hearing thresholds between the two groups of subjects, mainly in $3000 \mathrm{~Hz}(\mathrm{p}=0.000081 \mathrm{RE})$ and $\mathrm{p}=0,000021$ $\mathrm{LE}), 4000 \mathrm{~Hz}(\mathrm{p}=0,000003$ and $\mathrm{p}=0.000000 \mathrm{OE})$, $6000 \mathrm{~Hz}(\mathrm{p}=0.000295 \mathrm{RE}$ and $\mathrm{p}=0.000010 \mathrm{LE})$ and $8000 \mathrm{~Hz}(\mathrm{p}=0.008836 \mathrm{RE}$ and $\mathrm{p}=0.000378 \mathrm{LE})$.

The analysis of similarities between the hearing thresholds in the left and right ears for both groups, considering the significance level of 5\% showed no significant differences between the right and left ears for both groups separately, except for the $500 \mathrm{~Hz}$ frequency of for the group of non-exposed subjects $(\mathrm{p}=0.005)$. 
TABLE 1. Standard deviation of the averages of hearing thresholds in the two groups.

\begin{tabular}{|c|c|c|c|c|c|c|c|c|c|c|c|c|c|c|c|c|}
\hline \multirow{2}{*}{$\begin{array}{l}\mathrm{F} \\
\mathrm{Hz}\end{array}$} & \multicolumn{8}{|c|}{ Right ear } & \multicolumn{8}{|c|}{ Left ear } \\
\hline & 250 & 500 & 1000 & 2000 & 3000 & 4000 & 6000 & 8000 & 250 & 500 & 1000 & 2000 & 3000 & 4000 & 6000 & 8000 \\
\hline G1 & 7,22 & 8,97 & 12,94 & 19,55 & 21,61 & 19,66 & 21,12 & 24,01 & 8,63 & 9,89 & 12,85 & 18,55 & 20,49 & 17,13 & 20,76 & 22,85 \\
\hline $\mathrm{G} 2$ & 8,90 & 8,72 & 8,66 & 11,12 & 14,24 & 15,95 & 16,99 & 19,38 & 11,14 & 9,75 & 8,89 & 13,35 & 13,42 & 13,28 & 16,30 & 16,51 \\
\hline
\end{tabular}

$\mathrm{F}=$ Frequiência.

\section{Discussion}

In this study, the two groups are similar in age distribution, making possible a comparison between tonal thresholds of subjects having a history of exposure to noise and those without it.

As for the history of time of exposure to noise in work activities, we noticed that it varies from eight to twenty two years (average $=19$ ). According to the Brazilian National Committee of Noise and Audition Preservation13 NIHL generally reaches its maximum level for 3, 4 and $6 \mathrm{kHz}$ frequencies after ten to fifteen years of exposure to noise under stable conditions, which justifies the presence of NIHL in the evaluated group.

As for the hearing profile, we noticed that $80 \%$ of subjects (57 cases) have unilateral or bilateral neurosensorial hearing alterations. Other international 14-16 and Brazilian 17-18 studies show a very high predominance of hearing alterations among old people from 60 years of age. Brant and Fozard 5 found a $33 \%$ incidence of neurosensorial hearing alterations compatible with presbiacusy in the age group from 65 to 74 years of age. In the group of this study, the incidence of neurosensorial hearing alterations was higher in the age group from 50 to 70 years of age, perhaps because it is a population assisted by the clinic-school and that asked for audiology services due to some hearing complaint. The analysis carried out by this study is restricted to the studied group, and other studies would be important having other populations for comparison of the findings.

In the group having a history of exposure to occupational noise, there are more cases of neurosensorial hearing alterations (33 bilateral cases and two unilateral cases - 49,3\%), showing the aggravation of the hearing stress by age in the presence of exposure to noise, as other studies have shown $7,10,14$. In our group, only one had normal audition, while others had audiograms compatible with NIHL.

There is a significant dependence relation of exposure to noise and neurosensorial hearing loss, as well as a higher risk of developing neurosensorial hearing loss in the group with ages from 50 to 70 years and a history of exposure to noise in work. Gates et al8 analyzed audiometries of a group of men for 15 years, using Framingham Cohort Study, comparing audiometries of subjects (done when they had an average 64.1 years of age) with a second one (done when they had an average 78.5 years of age), in a universe of 203 audiometries, and they observed a high incidence of changes in hearing thresholds due to aging in the group, which had presented, in the first audiometry, an acoustic notch similar to that of NIHL. This finding showed a higher hearing stress in cases that were already presenting NIHL characteristics.

Graphs 1 and 2 show that the most affected frequencies in the group with a history of exposure to noise were $3000,4000,6000$ and $8000 \mathrm{~Hz}$, compatible with NIHL, while the least affected ones, both among subjects with a history of exposure to noise and those without it, are 500, 1000 and $2000 \mathrm{~Hz}$. Corso 7 and Kwitko19 studied the effects of presbiacusy and noise on workers, considering NIHL and presbiacusy as additive, which makes their effects to superpose in the cochlea, harming hair cells.

\section{Conclusion}

The group of men with ages from 50 to 70 years that had a history of occupational exposure to noise with a hearing profile suggestive of NIHL had worse hearing thresholds from $3000 \mathrm{~Hz}$ than the group without it. This means that for the subjects of this study, the impact of noise was more harmful to the cochlea than the natural stress due to age.

On the basis of these findings, it is recommended to consider the contribution of each factor, age and exposure to noise, for subjects from 50 years and more. 


\section{References}

1. Russo ICP, Santos TMM. A prática de audiologia clínica. São Paulo: Cortez, $4^{a}$ edição; 1993.

2. Signorini T. A deficiência auditiva do idoso e sua implicação na comunicação [dissertação]. São Paulo: PUCSP; 1989.

3. Silveira KM. A percepção da deficiência auditiva em um grupo de idosos institucionalizados da cidade de Franca - SP [dissertação]. São Paulo: PUCSP; 1997.

4. Baraldi GS, Almeida LC e Borges ACC. Evolução da perda auditiva no decorrer do envelhecimento. Rev Bras Otorrinolaringol. 2007;73(1):64-70.

5. Brant LJ, Fozard JL. Age changes in pure tone hearing thresholds in a longitudinal study of normal human aging. J Acoust Soc Am 1990; 88:813-20.

6. Phaneuf R, Hetu R. An epidemiological perpective of the causes of hearing loss among industrial workers. The journal of Otolaryngology 1990; 19(1):31-40.

7. Corso JF. Age correction factor in noise-induced hearing loss: a quantitative model. Audiology. 1980;19:221-32.

8. Gates GA, Schmid P, Kuyawa SG, Wan B, D'Agostino R. Longitudinal threshold changes in older men with audiometric notches. Hearing Research. 2000;141:220-8.

9. Toppila E, Pyykko I, Starck J. Age and noise-induced hearing loss. Scandinavian Audiology. 2001;30:236-44.

10. Ferrite S, Santana V. Joint effects of smoking, noise exposure and age on hearing loss. Occupational Medicine. 2005;55(1):48-53.
11. Ramos LR, Rosa TEC, Oliveira ZM, Medina MCG, Santos FRG. Perfil do idoso em área metropolitana na região sudeste do Brasil: resultados de inquérito domiciliar. Rev. Saúde Pública. 1993;27(2):87-94.

12. IBGE Instituto Brasileiro de Geografia e Estatística. Tábulas completas de mortalidade; 2003. [site da internet]. Disponível em: http://www1.ibge.gov.br/home/presidencia/ noticias/noticia_visualiza.php?id_noticia $=266 \&$ idpagina $=1$, acessado em 26/06/2007.

13. Comitê Nacional de Ruído e Conservação Auditiva Boletim número 1 - Perda Auditiva Induzida por Ruído Relacionada ao Trabalho. São Paulo; 1994 (revisto em 1999).

14. Abdel-Hamed O, Khatib OM, Aly A, Morad M, Kamel S. Prevalence and patterns of hearing impairment in Egypt: a national household survey. East Mediterr Health J. 2007;13(5):1170-80.

15. Chang HP, Chou P. Presbiacusis among older chinese people in Taipei, Taiwan: a community-based study. International Journal of Audiology. 2007;46(12):738-45.

16. Huang T. Age-related hearing loss. Minnisota Medice. 2007;90(10):48-50

17. Pinheiro MMC, Pereira LD. Processamento auditivo em idosos: estudo da interação por meio de testes com estímulos verbais e não verbais. Rev Bras Otorrinolaringol 2004; 70(2):209-14.

18. Veras RP, Matos LC. Audiology and aging: literature review and current horizons. Rev Bras Otorrinolaringol (Engl ed). 2007;73(1):122-8.

19. Kwitko A. Avaliação da perda auditiva ocupacional e da presbiacusia:uma aplicação da análise de components principais. Acta Awho. 1997;16(2):54-65. 